\title{
A molecular approach for the identification of drought-resistant rapeseed genotypes based on gene expression
}

\author{
Oana-Maria BOLDURA*, Sorina POPESCU, Radu SUMALAN \\ Banat University of Agricultural Sciences and Veterinary Medicine "Regele Mihai I al Romaniei" \\ Timisoara, Romania \\ *Corresponding author, email: oanaboldura@gmail.com
}

Bulletin UASVM Animal Science and Biotechnologies 72(1) / 2015

Print ISSN 1843-5262; Electronic ISSN 1843-536X

DOI:10.15835/buasvmcn-asb:10752

\begin{abstract}
Areas affected by drought have lately extended all over the world. Rapeseed (Brassica napus L.), one of the most important species for oil production, is sensitive to drought stress mainly during the early vegetative growth stage. The comparative proteome analysis pointed out that heat shock proteins 90 (HSP 90), 70 (HSP 70) and beta-2 tubulin have a role in the drought tolerance of rapeseed. The aim of this work was to develop a molecular approach suitable for the identification of the drought resistant rapeseeds genotypes and, at the same time, to study the tolerance mechanism related to specific genes expressions. The primers for the mentioned genes were designed according to data from NCBI Data Base and the genes expression was evaluated by RT- PCR technique. The total RNA was extracted, the cDNA was synthesized and the specific genes were amplified, the process being followed up in the presence of SYBR Green dye. The genes expression was investigated for two variants - control plants and drought stressed plants. It was found that all of the studied genes were up-regulated in known as tolerant genotype and therefore they were over-expressed in drought conditions. The most obvious differences were pointed out for HSP 70 gene.
\end{abstract}

Keywords: drought, gene expression, rapeseed, RT-PCR

\section{INTRODUCTION}

Canola is becoming a very important oil seed crop worldwide. Its oil is of premium quality due to its low erucic acid and glucosinolates content (Din et al., 2011).

The most important stress factor which endangers cultivation and successful production of canola is drought.The best way of combating drought is using the varieties which have more tolerance for drought.

The comparative proteome analysis of drought-sensitive and drought-tolerant rapeseed pointed out that HSP 90, and elongation factor EF2 , has a role in the drought tolerance of rapeseed and that the decreased levels of heat shock protein
70 and tubulin beta- 2 in the drought-sensitive and hybrid F1 lines might explain the reduced growth of these lines in drought conditions (Mohammadi et al., 2012). From these literature data, three proteins - Heat Shock 90(HSP 90), Heat Shock 70 (HSP 70), and beta-2 tubulin - were selected to be analysed in terms of synthesis level in tissues in case of drought stress.

\section{AIMS AND OBJECTIVES}

The aim of this work was to develop a molecular approach for the identification of the drought resistant rapeseed genotypes, based on HSP 90, HSP70 and beta- 2 tubulin gene expression. 


\section{MATERIALS AND METHODS}

In the described experimental series, 9 rapeseed hybrids were studied, drought tolerant Crouse: drought sensitive: Excel and of unknown tolerance 1, 2, 3, 4, 5, 6 and 7. For each hybrid, two experimental variants were obtained: control unstressed and drought stressed. From extracted and purified RNA, cDNA was synthesis using a reverse-transcription kit following the protocol of the manufacturer. The cDNA was quantified and used as template in the SYBR Green qPCR reaction. For the relative quantification the $\Delta(\Delta \mathrm{Ct})$ method was used (Livak and Schmittgen, 2001).

\section{RESULTS AND DISCUSSION}

The three proteins Heat shock 70 (HSP 70), Heat shock 90-2 (HSP 90) and $\beta$-tubulin sequences could be assessed in the NCBI Data Base, according to their accession number and primers were designed. As a reference gene in RT-PCR analysis, actin gene was used. Based on protein sequence, the specific messenger RNA was revealed, followed by the complementary DNA (cDNA), reversetranscription. It turned out that the best primers combination is $1.5 \mu \mathrm{l}$ from the forward primer ( 5 $\mu \mathrm{M})$ and $0.25 \mu \mathrm{l}$ from the reverse primer $(5 \mu \mathrm{M})$ for HSP 70 gene, and $4.5 \mu$ from the forward primer $(5 \mu \mathrm{M})$ and $1.5 \mu \mathrm{l}$ from the reverse primer $(5 \mu \mathrm{M})$ for the actin gene.The reaction was run for the two genes with duplicates of each cDNA sample in the presence of SYBR Green dye. Fluorescence was recorded in real time.

For each sample, the number of threshold cycles (Ct) was determined. For relative quantification, the $\Delta(\Delta \mathrm{Ct})$ method was used. According to this method, the $\mathrm{R}$ (the relative ratio between the control and stressed variant) is calculated by using the formula $\mathbf{R}=2^{-\Delta \Delta \mathrm{ct}}$

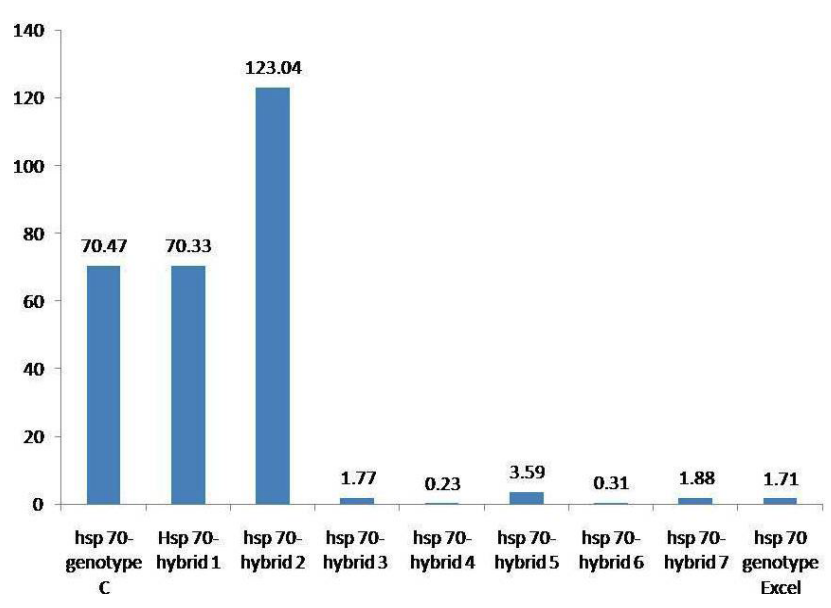

Fig. 1: Relative quantification ratio for all studied genotypes

\section{CONCLUSION}

It was found that HSP70, not HSP 90, genes could be used as a marker for the relative evaluation of drought resistance.The obtained results pointed out a higher tolerance to drought for the Crouser genotype and also for Hybrids 1 and 2. For the other hybrids, the HSP 70 gene expression was much lower, indicating a low tolerance to drought.

\section{REFERENCES}

1. Din J, Khan SU, Ali I, Gurmani AR (2011) Physiological and agronomic response of canola varieties to drought stress, The Journal of Animal \& Plant Sciences, 21(1), Page: 7882, 1018-7081

2. Livak KJ, Schmittgen TD (2001) Analysis of relative gene expression data using real-time quantitative PCR and the $2 \Delta \Delta \mathrm{C}(\mathrm{T})$ Method. Methods 25 (4): 402-408

3. Mohammadi PP, Moieni A, Komatsu S (2012), Comparative proteome analysis of drought-sensitive and droughttolerant rapeseed roots and their hybrid F1 line under drought stress, Amino Acids;43(5):2137-52. doi: 10.1007/s00726-012-1299-6. 